Festival or to be kept informed of further developments, should contact the U.K. African Festival Committee at 46 Kingsway, London WC2 B 6EN. Telephone o1-242-3409.

\title{
Fontes Historiae Africanae
}

THE Fontes Historiae Africanae is a project concerned with the publication of written source materials for the history of Africa. It is supported by the International Academic Union, having been originally sponsored by the Czechoslovak Academy of Sciences and its first director was the Czech historian Professor Ivan Hrbek. The direction of the project was taken over by Professor John Hunwick of the University of Ghana on 3 January 1973.

In principle the Fontes project embraces the whole of Africa in the precolonial period, but it has been decided to concentrate first on the Arabic source materials, particularly those emanating from or concerned with Africa south of the Sahara. The most urgent need is to make a start in the publication of the source materials themselves in text and translation and the series is to be initiated with suitable texts which are brought to the attention of the director and the editorial committee. It is also planned to prepare, in collaboration with a number of scholars, a critical bibliography of Arabic sources for African history already translated into any of the major European languages. Two texts with translations have already been accepted for publication and it is hoped that they will appear during the course of 1974. They are: Uthman dan Fodio, Bayan wujub al-hijra, edited and translated by Dr. F. H. Elmasri; Funj Land Charters, translated and annotated by Dr. J. Spaulding and M. I. Abu Salim. It is expected that about two volumes would appear every year for the foreseeable future. Further information will be given in due course.

The director of the Fontes Historiae Africanaia would be pleased to hear from institutions and individual scholats of work they have in progress relevant to the central aims of the project or to wider problems of Arabic source material for African history. Such information and any inquiries about the Fontes project should be addressed to him at: Department of History, P.O. Box I 2, University of Ghana, Legon, Ghana.

\section{SEPA (Science Education Programme for Africa)}

SEPA was established in 1970 and grew out of the African Primary Science Programme formed in Kano, Nigeria, in 1965 . The present Chairman is Dr. N. H. Ayodele Cole, University of Sierra Leone, and the Executive Secretary Dr. H. M. Dyasi. There are seven fullmember countries of SEPA at present and negotiations are in progress to encourage other countries as well as French-speaking territories to participate in its activities. The aims of SEPA are to establish a clearing house for the exchange of information on science education in Africa, through workshops, conferences, and publications; to support and encourage the production of instructional materials and the manufacture of scientific equipment and materials from locally available resources; to co-operate with other educational programmes and to establish liaison with science education programmes throughout member countries.

SEPA is supported by the annual membership contributions of Member States, and USAID through EDC, Carnegie Corporation, CEDO, and UNESCO Division of PreUniversity Science and Technology Education. Inquiries should be directed to: The Executive Secretary, SEPA, Post Office Box M. I88, Accra, Ghana.

\section{Center for Translation and Intercultural Communication}

THrs centre has been established by the Department of Comparative Literature at the State University of New York at Binghamton with a grant from the U.S. Office of Education 
through the National Endowment for the Humanities. The Department is training professional translators in the humanities and the sciences and developing new learning methods in the field of intercultural communications. Activities have also been expanded in the field of literary translation and a translation workshop has been operating annually since spring $197 \mathrm{I}$ in French, German, Spanish, and Latin. With the creation of the centre the curriculum has been widened to include classical and modern Chinese, Russian, Polish, and Yiddish; staff have also been engaged for Biblical and modern Hebrew.

The centre intends to hold a regular series of forums on subjects related to translation and to act as a clearing-house for translations in progress, translations under contract, and works needing translation. The Director of the Centre is Mr. Gerald Gillespie, Professor of German and Comparative Literature. Communications should be addressed to Ms. Marilyn Gaddis Rose, Chairman of the Department of Comparative Literature and Acting Director of the Centre, or to Mr. Ramon Layera, Ibero-American Consultant and Administrative Assistant, at SUNY Binghamton, New York r 390 r.

\section{International African Bibliography}

THE bibliographical card-index service offered until 1972 by the International African Institute is now available in the Library of the School of Oriental and African Studies.

Cards giving details of monographs, pamphlets, articles, conference papers, and items within collected works are arranged by geographical region/country, thence the subject. The subject approach is a feature not included in the quarterly International African Bibliography. The majority of entries at present refer to works published in 1972 and 1973 . The card-index will, of course, grow as fresh cards are added annually. An author card-index is also available.

Staff and students of the School may consult the card-index in Room F2 of the Library.

\section{OXFAM: New Voluntary Overseas Group}

Proples from the developing countries of Africa, Asia, and Latin America are being sought by Oxfam's branch in Central London for a new voluntary group designed to back up the agency's world-wide development programme. The group will have two principal functions: to advise on policies that would encourage a more positive attitude towards world development, and to help generate new support for Oxfam's work. It will be one of several special groups recently set up by Oxfam in London. This first Overseas Group will be limited to people living in and around London. Anyone interested in further information should contact Miss Jeannie Murray, Oxfam Regional Office, I 2 Crane Court, Fleet Street, London EC4 (Telephone: o1-353-5701).

\section{'Cultures et développement' (Université Catholique de Lowvain) vol. v, no. 4.} Articles

Richard D. Ralston. Political Change in Colonial African Leadership (ca. 1914-ca. 1945): American and Afro-American Influences.

Béatrice de Sinçay. Christianisme et développement au Rwanda Central.

Samuel Decalo. The Colonel in Command Car. Towards a Re-examination of Motives for Military Intervention in Africa.

Marc A. Tessler. Le concept de modernité au miroir des sciences sociales.

Aryé Globerson. Participation et développement. 